\title{
The Cultural and Environmental Unsoundness of the Chinese Public Squatting-Type Toilet: A Case Study toward a Sustainable Excreta Treatment System
}

\author{
Jin-Soo Chang ${ }^{\dagger}$ \\ Molecular Biogeochemistry Laboratory, Biological and Genetic Resources Institute (BGRI), Daejeon 305-811, Korea
}

\begin{abstract}
The inconvenient truth of sustainable public squat toilet culture varies among nationalities. This culture may be comfortable to the people of China, yet uncomfortable to the non-Chinese, according to the adequate environmental management in Yanbian Korean Autonomous Prefecture (YKAP), northern China. We conducted a series of field surveys and individual interviews (Chinese $\mathrm{n}=1,000$ and non-Chinese [foreign visitors] $\mathrm{n}=100$ ) on several aspects of the public squat toilet: structural properties, waste disposal methods, important factors, and overall satisfaction level. The significant factors in response to the public squat toilets were cleanliness, odor, toilet paper, temperature, soap, other facilities, and presence of cubicles. These factors should be policy priorities of the local government. In addition, $66.2 \%$ of Chinese and $91 \%$ of foreign visitors desired type E toilets (two full-high partition walls and a door). The results illustrate the nature of a sustainable and beautiful approach to the culturally and environmentally sound management of various types of public squat toilet in YKAP. The government needs to focus on the future-oriented and excreta treatment management of the sustainable toilet culture for residents and visitors of YKAP.
\end{abstract}

Keywords: Bio-toilet system, Composting toilet, Public squatting-type toilet, Water-flushing toilet, Yanbian Korean Autonomous Prefecture

\section{Introduction}

Squat toilets are also known as 'alla turca' in Europe, 'alla franca' in Italian, and 'kakkoos' in Malayalam or Iranian. To use a squat toilet, users place their feet on footrests, facing the entrance to the cubicle [1-3]. Squat toilets are also known as 'all Turca type from Europe', 'alla Franca type from Italian', and 'kakkoos' in Malayalam or Iranian toilet. In them, the user puts their feet on footrests, facing the entrance to the cubicle [2,3]. Squat toilets, known as "Water toilets" in India, were built by the Harappan civilization as early as 2500 BC [4]. In the Korean Annals of the Joseon Royal Dynasty in 1st century BCE, the laws enacted since 2003 were promulgated [5]; flushing squat toilets were also present at the Minoan palace in Knossos, Greece in 1700 BC [6]. Proper, shaped distinctively as a rectangular oval with a urine guard, with composting, flushing, and ecological types [7]. In parts of Korea, Japan, Taiwan, China, and several other Asian countries, squat toilets are still prevalent. In poor rural areas of Yanbian Korean Autonomous Prefecture (YKAP), modern squat toilets are nothing but communal eco-toilets made of wood, cloth, or concrete using wastewater technology high-efficiency toilets and/or incinerating toilets, similar to toilets in the late 19th and early 20th centuries [5, 8, 9]. Modern public sit and squat toilets date from the late 19th century, when sewer systems and water supplies provided hygienic means of dealing with waste, facilitated by public health legislation that permitted local authorities to place public squat toilets in town centers [6].

According to Langergraber and Muellegger [10], major global sanitation problems include poor sanitation coverage and the absence of operating sewerage systems. In several studies of sanitary rural domestic flushing toilets, different types of toilets are identified: water-flushing toilets, bio-toilet systems, sawdust-matrix composting toilets, and alternative sewage systems [11-15]. Private and public composting and dry toilets re-use of compost, urine, and/or feces as manure in agriculture, the historical process that led to embedding water-flushing toilets, and solutions that use less water to dispose of toilet waste are all unknown [12, 13]. The survival of fecal coliform in dry toilets needs to be addressed in order to reduce illnesses caused by manual-oral transmission of fecal pathogens [16]. Using the multicriteria decision analysis, microbiological assessments on the ability of compost toilet systems, commonly used in Denmark,

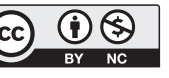

This is an Open Access article distributed under the terms of the Creative Commons Attribution Non-Commercial License (http://creativecommons.org/licenses/by-nc/3.0/) which permits unrestricted non-commercial use, distribution, and reproduction in any medium, provided the original work is properly cited.
Received January 25, 2014 Accepted February 28, 2014

${ }^{\dagger}$ Corresponding Author

E-mail: jinsoosu@daum.net

Tel: +82-42-864-0418 Fax: +82-42-864-0419 
a

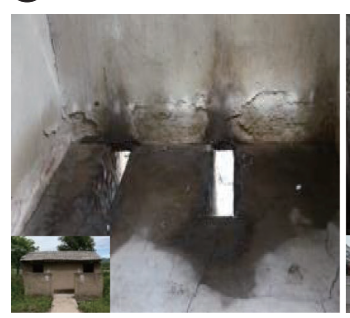

Type B

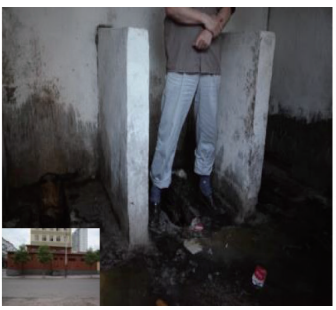

Type C

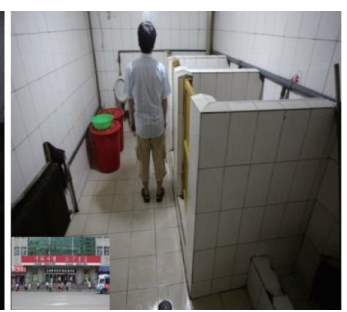

Type D

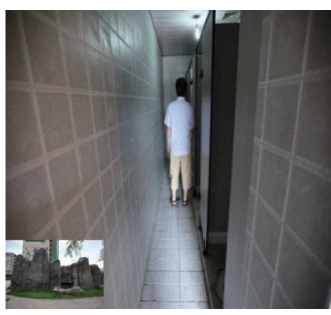

Type E

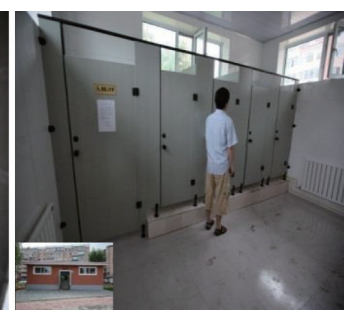

b

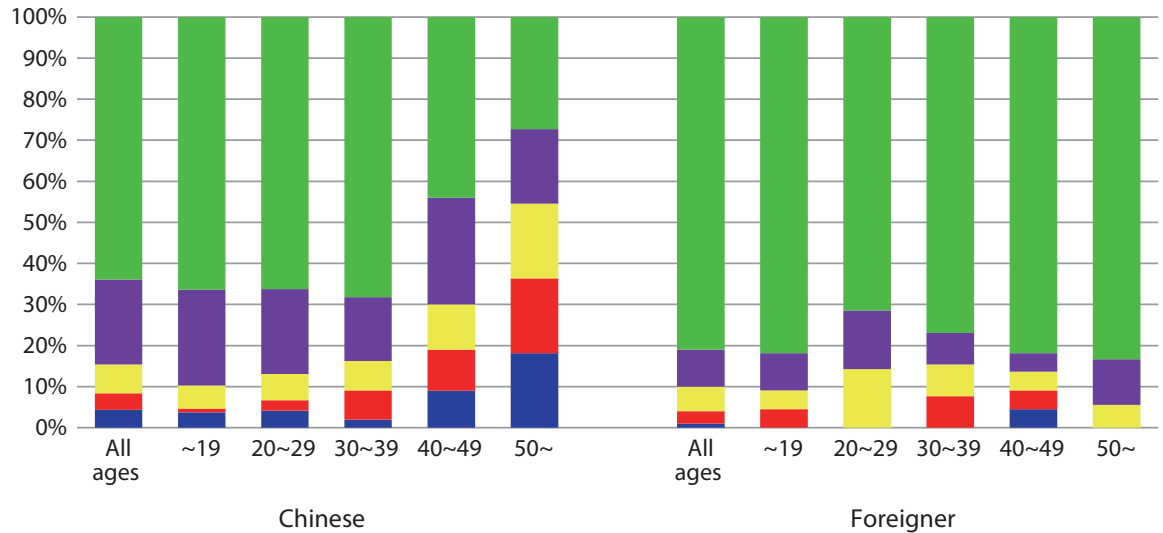

- Type A: No partition wall or door

- Type C: Two waist-high partition walls and a door

Type E: Two full-high partition walls and a door
- Type B: Two waist-high partition walls and no door - Type D: Two full-high partition walls and no door

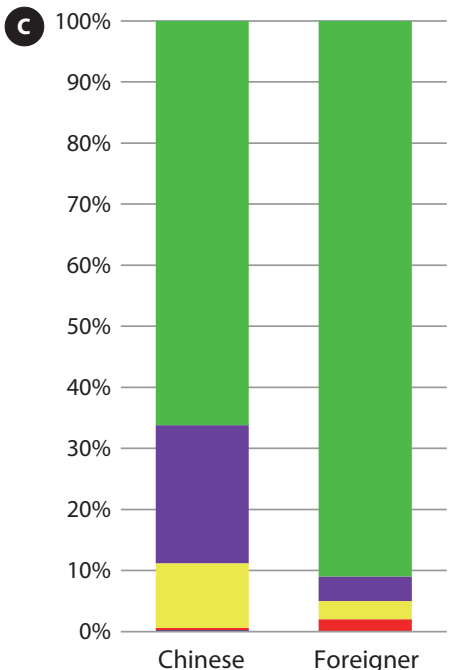

Fig. 1. (a) Five types (types A through E) of public squat toilet characteristics of Yanbian and the related survey results. The questionnaire questions and answers: (b) acceptable type to use and (c) a recommended future type in Yanbian Korean Autonomous Prefecture.

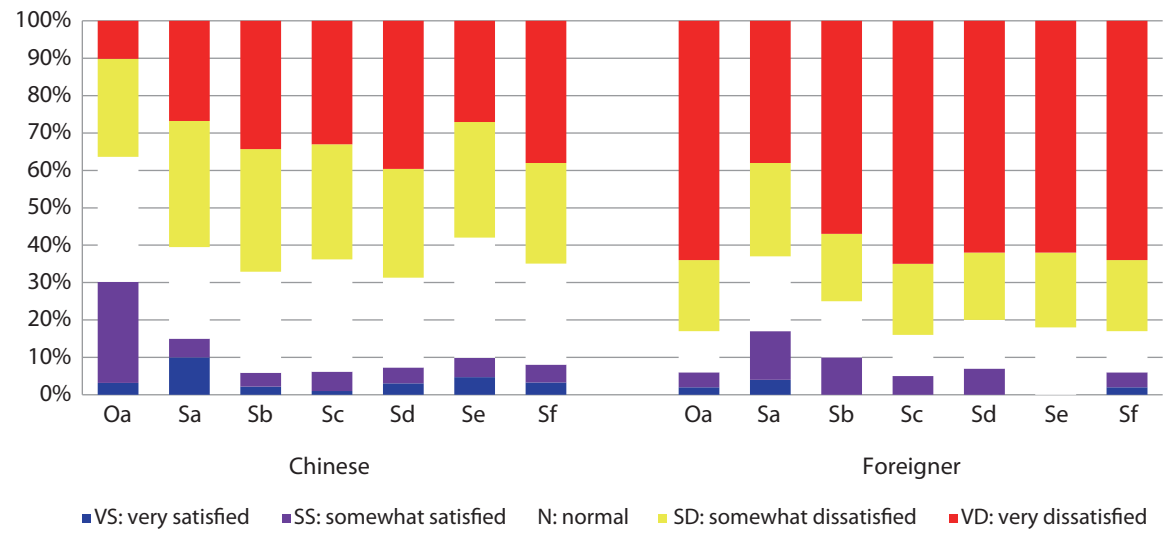

Fig. 2. Summary of satisfaction of public squat toilets (questionnaire results). to reduce fecal pathogens [17-19] suggest that innovative toilet technology and urine source separation (i.e., NoMix-technology) leads to other fields of technological household innovations and sustainable urban water management systems. The ergonomic public squat toilet design can also improve the public environment aesthetically, which should be considered in the decisionmaking process of public infrastructure. Both theoretical and practical considerations of alternative sewerage systems $[15,20$, 21] should be considered, as well. Overall, studying public squat toilets as they relate to riverside/stream pollution may reduce human feces with regard to sanitation. Public squat toilets, urine source separation, and public awareness of the functions of eco- logical toilet systems are strong predictors of the potential for human health damage $[2,19,20,22]$.

In this paper, through a case study in YKAP, we explore the public squat toilet in terms of the inconveniences it brings to the development of a sustainable toilet culture. In addition, we individually interviewed 1,000 Chinese and 100 non-Chinese people on their attitudes toward the exterior of public toilets. According to the results, people found squat toilets to be beautiful from the outside, yet, uncomfortable in practicality. The specific questions were based on the five types of public squat toilets in YKAP (Fig. 1), the satisfaction and related factors (Fig. 2 and Table 1), and the types of treatments of excreta in place (Fig. 3 and 


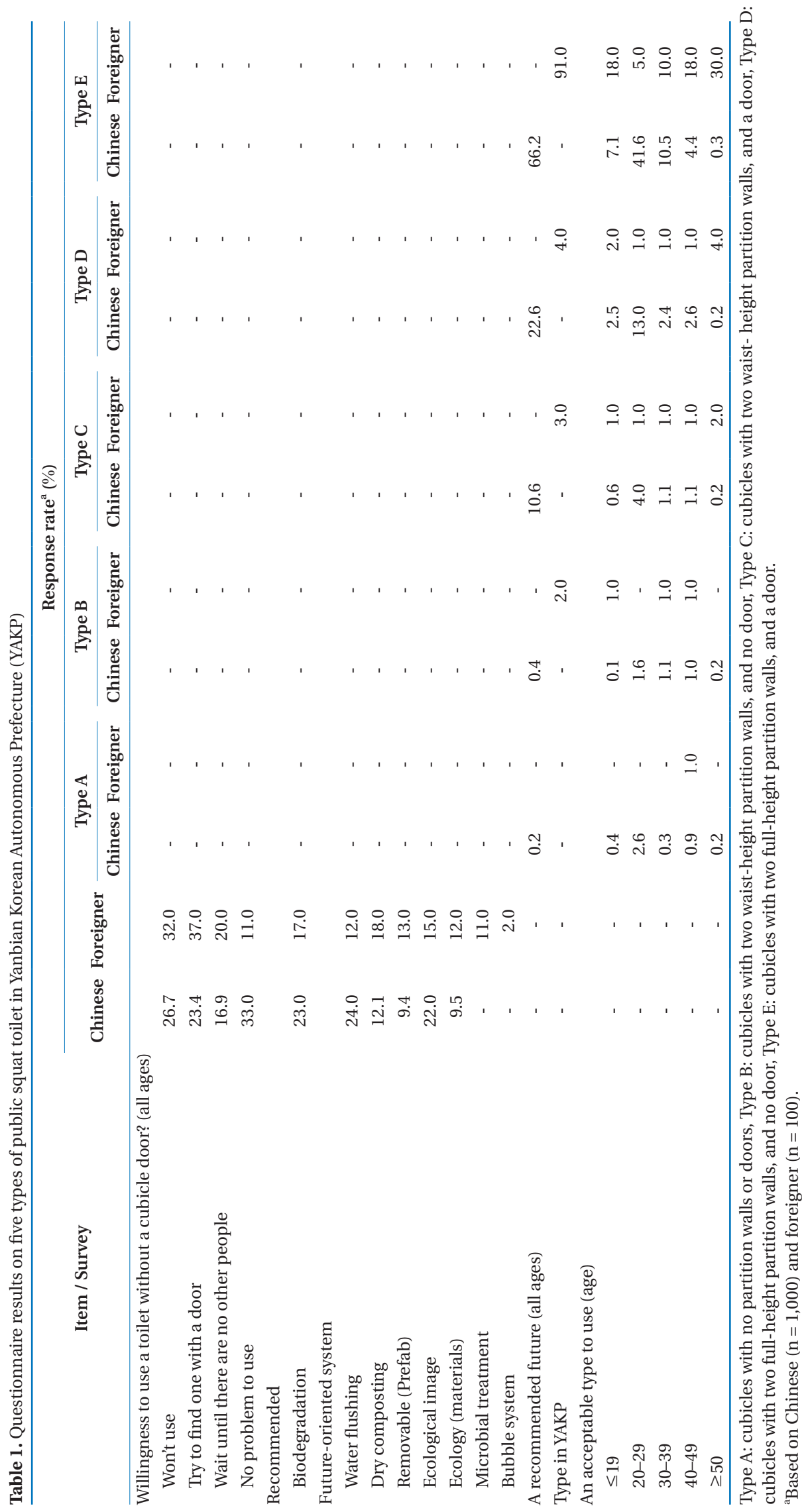


a
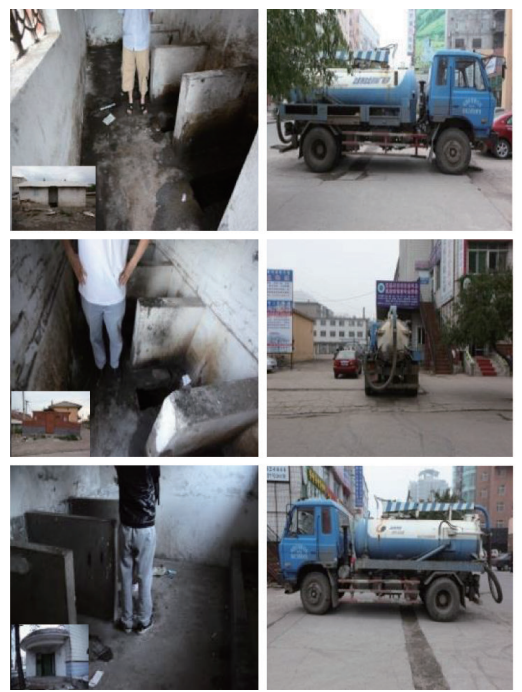

b
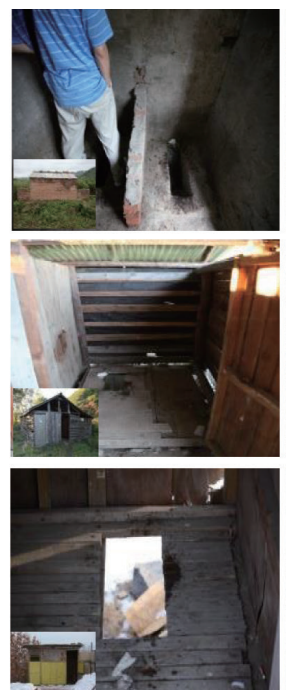
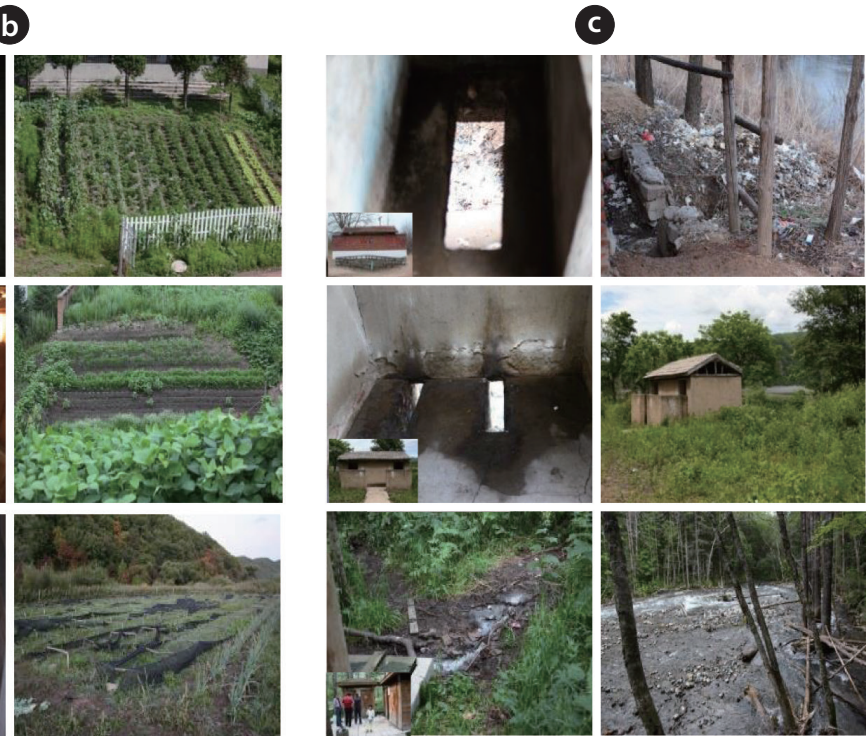

Fig. 3. Three different types of excreta treatment system of public squat toilets by treatment of excreta: (a) honey wagon toilet, (b) fecescomposting toilet, and (c) release into river.

Table 2). Our questions obtained information on participant's knowledge of public squat toilets and whether or not they preferred such methods. We also attempted to gain critical sources related to our study. In order to compare the environmental properties of five different types of public squat toilets, we investigate and evaluate the impacts of each toilet on people as well as the impact on the treatment management of excreta.

\section{Materials and Methods}

\subsection{Field Description and Survey}

Yanji is the capital city of the Yanbian Korean Autonomous Prefecture (YKAP), which is located in the Jilin province of China. The YKAP has a population of 2.18 million people and covers an area of $43,559 \mathrm{~km}^{2}$. It is located in the northeastern region of China, near Russia, and North Korea. We examined five different types of public squat toilets in YKAP (see Fig. 1). In addition, we evaluated the movement of the 'honey wagon', which handles solid waste, different methods of composting of feces, and fecal discharge into rivers.

\subsection{Summary of Interviews and Questionnaire Analysis}

In this study, from January to December 2010, 1,000 residents and 100 foreign visitors in YKAP who had previously utilized the five types of public squat toilets were interviewed individually. For details of data collection, response rates, toilet visits, and information about various characteristics, see Tables 1 and 2. Visitors to the toilets were asked to fill out a questionnaire containing a series of detailed questions about environmental quality, recommended future systems, various aspects of satisfaction, important factors as a public-toilet, communal usage, frequently used systems, public squat toilets in the future, acceptable structures, and overall satisfaction level (see Tables 1 and 2). We analyzed the data with SPSS ver. 15.0.1.1 (SPSS Inc., Chicago,

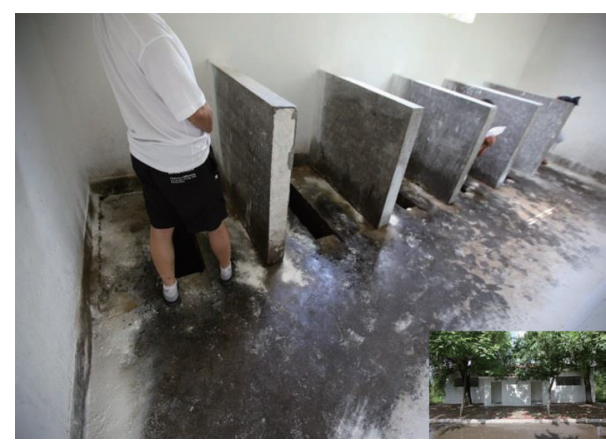

Fig. 4. Typical use of a public squatting-type of public toilet.

IL, USA) spreadsheet and statistical results are summarized in Tables 1 and 2. The entire questionnaire, including the methodological details, is presented in Tables 1 and 2. The following is a summary of the questions and possible responses (provided in the supporting information). The questionnaire used in this study was a modified version of the one used by Blum et al. [22], based on the results obtained in Zhang et al. [11].

\section{Results and Discussion}

\subsection{Sustainable Regional Culture}

We individually interviewed 1,100 people at the entrance to a public squat toilet in the sustainable regional culture of Yanji. The respondents' sex, age, important factors of toilets, ease of finding toilets, and users' satisfaction were assessed (Table 2). We believe that our questionnaire can inform policies addressing the concerns of our respondents (Fig. 5). According to Borsuk et al. [18] and Lienert and Larsen [23], a policy of public chemical or composting toilet has been followed since the 20th century [4, 


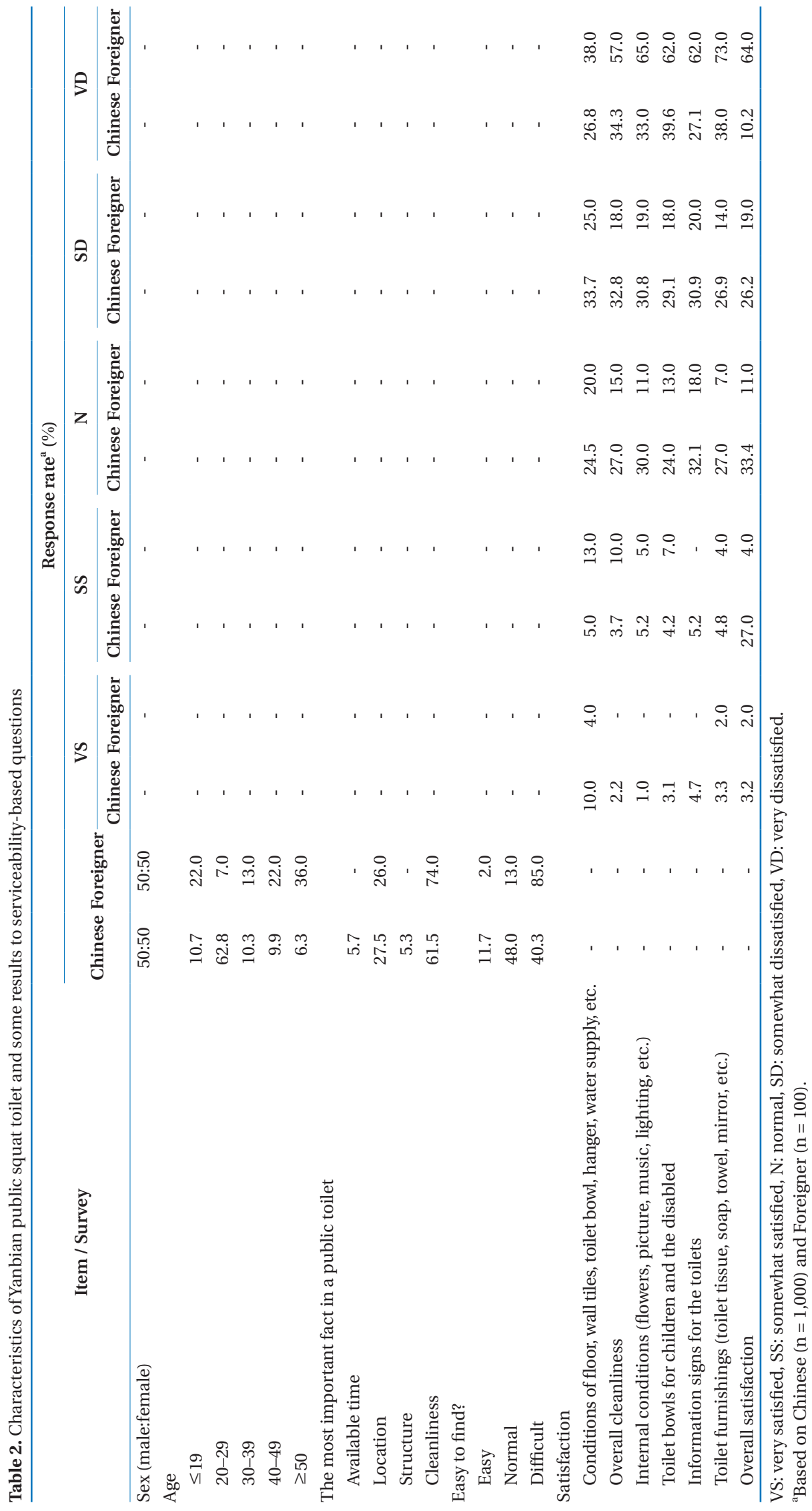



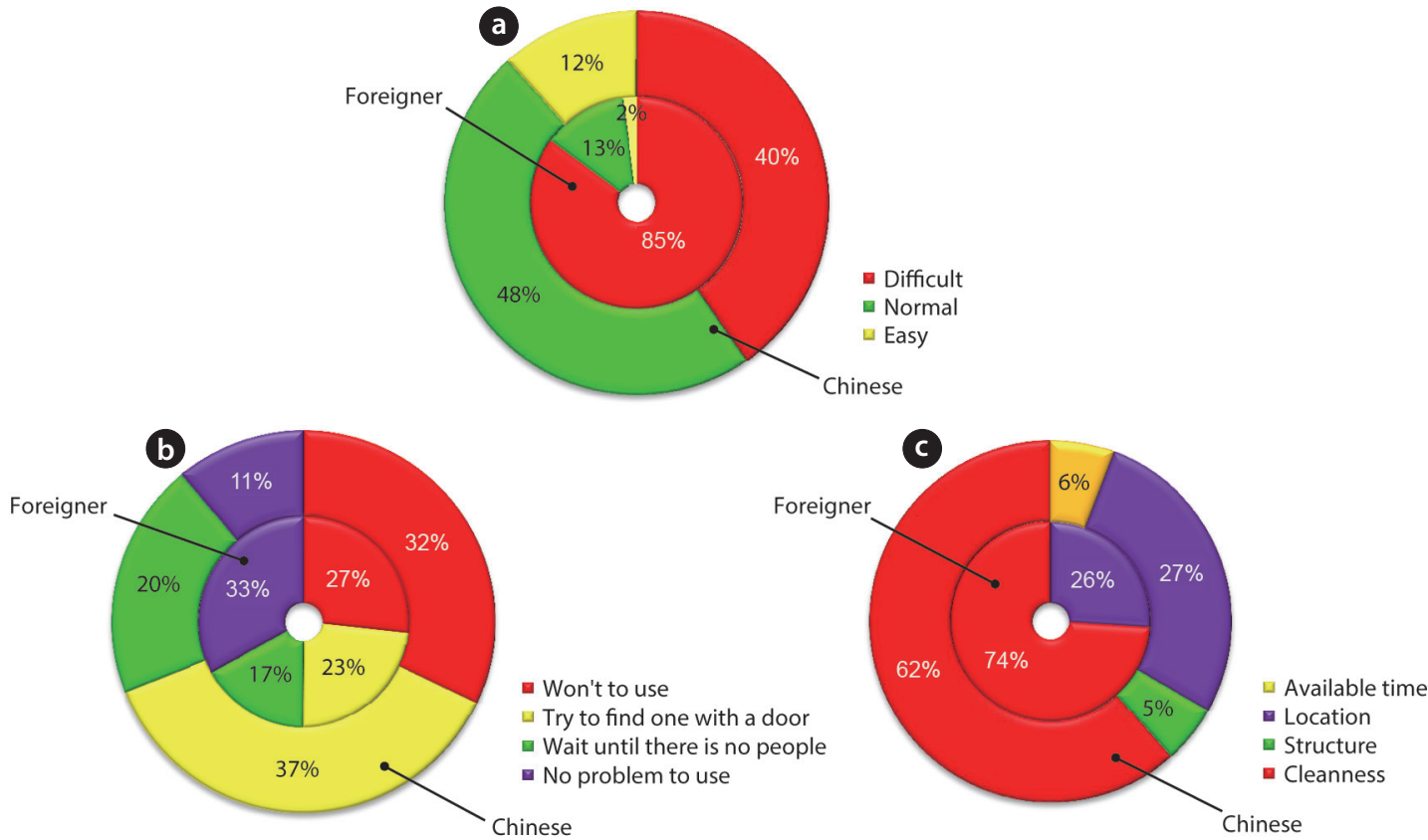

Fig. 5. Three questionnaire questions and answers: (a) easy to find, (b) willing to use a public squatting-type toilet with no door, and (c) most important factor as public squatting-type of public toilet.

6, 9]; however, the conditions in YKAP limit the generalizability of their findings to our situation [3]. We discovered that streams in the area were exposed to urine and feces from squat toilets. As shown in Fig. 3, there are three main types of public squat toilets in YKAP based on the mode of excreta treatment: honey wagon toilets, feces-composting toilets, and feces-treating and feces-releasing toilets. Tables 1 and 2 provide further details. Public squat toilets in YKAP are of a common style across northeast Asia that is amenable to conversion to sustainable eco-toilets. Squat toilets also clearly reflect Korean architectural features [3, 7]. However, they also reflect the survival and perpetuation of the squat toilet, fundamentally, a Chinese cultural export.

\subsection{Five Different Types of Public Squat Toilets}

Fig. 1 presents the five different types of public squat toilets in YKAP: those without any partition walls or doors (type A), those with two waist-high partition walls and no door (type B), those with two waist-high partition walls and a door (type C), those with two full-height partition walls and no door (type D), and those with two full-height partition walls and a door (type E). The preferred types were type A (Chinese $0.2 \%$ ), type B (Chinese $0.4 \%$ and foreigner $2.0 \%$ ), type $\mathrm{C}$ (Chinese $10.6 \%$ and foreigner $3.0 \%$ ), type D (Chinese $22.6 \%$ and foreigner $4.0 \%$ ), and type $\mathrm{E}$ (Chinese $66.2 \%$ and foreigner $91.0 \%$ ) (see Fig. 1(c) and Table 2). Overall, we can observe the increasing popularity from type A to $\mathrm{E}$.

To our knowledge, this is the first study to evaluate public squat toilets by type and satisfaction in the context of sustaining the culture in the city of Yanji in YKAP. Of the five types of toilets outlined above, types A through D are the most common types in the city; however, type E toilets are being dispersed (Fig. 1(a) and Fig. 5(a)). According to Cai and You [20] and Mamee and Sahachaisaeree [21], disabled-access toilets are also expanding [24]. Our results prove that a large number of Chinese people, and even non-Chinese visitors, prefer the use of a toilet with a cubicle door. In addition, many Chinese and visitors have difficulty finding a toilet when in need, especially where there is no one around. The psychological discomfort of these findings demonstrates the need for friendly public toilet policies. The environmentally friendly public toilet policy needs to be driven by the government continuously. Furthermore, we recommend a no-fee policy and an increase in the availability of toilets.

If designers do not change the uncomfortable conditions surrounding public squat toilets in YKAP_-preferably by increasing the availability of the type E toilet, the most popular kind-it could result in further environmental damage and human inconvenience. However, ecological public squat toilet designs are very similar in design to toilets without sewage systems (Fig. 4) [20]. As part of the national development of China, the overall level of the public squat toilets is also in need for improvement, especially in terms of cleanness. Foreign tourists in types A and B toilets felt the inconvenience of public squat toilets. A measure to increase the number of type E toilets and hire more toilet cleaners is required to address the issues of cleanliness and privacy, respectively. It is not so difficult to find some destitute public-toilet managers, who have a one or some a public-toilet building as their living space. The Chinese government should consider this inconvenient truth.

\subsection{Respondent Satisfaction with Public Squat Toilets}

Table 2 and Fig. 2 display toilet measures-condition of floor, wall tiles, toilet bowl, hanger, water supply, overall cleanliness, internal condition (flowers, picture, music, lighting, etc.), disabled access, signs, toilet furnishings (toilet tissue, soap, towel, mirror, etc.), and overall satisfaction - regarded as significant. Overall, the respondents considered 'cleanliness and foul odor' as the most important factor, for implications of future policy 
priorities of the local government. The negative cleanliness evaluations were as follows: somewhat dissatisfied (SD; Chinese $32.8 \%$ and non-Chinese people [foreign visitors] $18.0 \%$ ) and very dissatisfied (VD; Chinese $34.3 \%$ and non-Chinese people [foreign visitors] 5.0\%). For internal conditions (flowers, picture, music, lighting, etc.), the evaluations results were as follows: SD (Chinese 30.8\% and non-Chinese people [foreign visitors] $19.0 \%$ ) and VD (Chinese $33.0 \%$ and non-Chinese people [foreign visitors] $65.0 \%$ ). For the overall satisfaction convenience, ratings included normal (Chinese $33.4 \%$ and non-Chinese [foreign visitors] $11.0 \%$ ) and VD (Chinese 10.2\% and non-Chinese people [foreign visitors] $64.0 \%$ ) (Table 1). With regard to toilet management, responses differed by age group with the younger respondents more averse to using less private toilets. Although most respondents were satisfied with the public squat toilets in YKAP, there is still room for improvement to adhere to the government tourist policy.

Various methods of treating waste from public squat toilets [25] have been reported. Methods include composting [9, 16, 22, 26], wastewater technology [8], microbiological treatment [17], sawdust matrices [14], water flushing [12], sewerage systems [15], and urine source separation [19]. However, in YKAP, the three different types of excreta treatment for public squat toilets are the honey wagon, feces composting, and fecal discharge to local rivers (Fig. 3). Honey wagon handling is a service for which 200 RAM (Chinese monetary unit) is charged (Fig. 3(a)). Honey wagon indicators and a natural sewerage system demonstrate that the method used to normalize the weighting technique has a considerable influence on which is found to be more sustainable [15]. Fig. 3(b) presents a typical method used in rural YKAP — moving feces to fields, to utilize as a fertilizer. Using feces as a fertilizer to grow healthy vegetables is the best possible form of sustainability in contrast to method C (Fig. 3), where dumping of waste in rivers engenders environmental pollution. The future policy of the Chinese government needs to develop based on these considerations.

With regard to the difficulty of finding a toilet, non-Chinese visitors responded as follows: difficult (85\%), normal (13\%), easy (2\%); Chinese responded to the same factor as difficult $(40 \%)$, normal (48\%), and easy (12\%) (Fig. 5). Fig. 5 also discloses the respondents' evaluations for willing to use a toilet without a doorall ages, non-Chinese won't use (27\%), will try to find one with a door $(23 \%)$, will wait until there are no people $(17 \%)$, and will use with no problem (33\%); Chinese won't use $(32 \%)$, will try to find one with a door $(37 \%)$, will wait until there are no people $(20 \%)$, and will use with no problem (11\%). For non-Chinese participants, the important factors in their evaluation of a toilet were identified as location (26\%) and cleanliness (74\%). For Chinese participants, the most important factors were as follows: vacancy $(6 \%)$, location $(27 \%)$, structure $(5 \%)$, and cleanliness $(62 \%)$ (Fig. 5). Fig. 4 shows a toilet with two waist-high partition walls and no door (type B), which is the most common type of public squat toilets in YKAP. Toilets without any partition walls or doors (type A) are also common. Respondents identified inconveniences regarding the well, door, and size of eco-toilets.

Langergraber and Muellegger [10] report that ecological public squat toilets are a way to solve the global sanitation problems, since flush toilets, a water-wasting technology, are neither an ecological nor an economical solution in either developed or developing countries. In Yanbian, however, solutions are complicated, in addition to the issues mentioned above, problems identified include lack of door locks and wet floors. As seen in Fig. 1(a), type A and B toilets, which the non-Chinese, in particular, had difficulty using appeared dirty to the point of causing revulsion. Moreover, these toilets are rather deep and can be dangerous to children under the age of 16 as well as the elderly [26,27].

With regard to other issues, Tung et al. [28] reported the influence of bathroom ventilation and toilet location on odor removal. Also, a better sanitation system, such as washing hands after toilet use, sustainable control of water-related infectious diseases, and interdisciplinary health-based systems, can improve the current situation [29, 30]. Various treatment methods have been tested, including breakdown of the products (toilet paper, tissues, and tampons) in natural environments [31], composting toilet systems [32], and grey water reuse for toilet flushing [33]. Some additional suggestions for better public squat toilet environments are as follows. The behavior of urinating in the street should be punishable by a fine. There are not enough women's public squat toilets and furthermore, the toilets are not warm. Bubble public toilet users feel uncomfortable with the bad bubble conditions. There should also be more toilets accessible to the disabled and to pregnant women. In the age of globalization, the improvement of the Chinese public squat toilets will be a great advantage not only for the Chinese people, but also for visitors.

\section{Conclusions}

In this study, we highlight an inconvenient truth in global toilet culture, the inadequacy of public squat toilets, and suggest future toilet models can be more hygienic. The Chinese government, in accordance with the international and Chinese opinions of public squat toilets, should consider new approaches. The major issues are privacy, excreta treatment, accessibility, conditions of facilities, cleanliness, amenities, safety for children and the elderly, toilet supplies, and sustainable systems for the future. Overall, malodorous, polluted public squat toilet conditions in Yanbian need improvement for the reputation of the region and for the quality of life of the people. Many users look for toilets in restaurants, Internet cafes, or shopping malls. Even though the public squat toilets in China are slowly improving, it is necessary to change the building practices and customary ways of using them.

\section{Acknowledgments}

We thank Dr. Min-Ho Chey, Hyung-Jin Mun, Miyoung Seo, for technical assistance and Dr. Chunzhi Cui, Dr. ImShik Lee for helpful advice. This work supported by a grant (No. 13BGRIA10-13-01) from Molecular Biogeochemistry Laboratory in the Biological and Genetic Resources Institute (BGRI and YUST Joint Program).

\section{References}

1. Mara DD. The design of pour-flush latrines. Washington: The World Bank; 1985.

2. Stanwell-Smith R. Public toilets down the drain? Why privies are a public health concern. Public Health 2010;124:613-616.

3. Korea Toilet Association [Internet]. Suwon: Korea Toilet Association; c2012 [cited 2014 Apr 15]. Available from: http:// 
www.toilet.or.kr/site/index.php.

4. Miller FP, Vandome AF, McBrewster J. Composting toilet. Saarbrucken: Alphascript Publishing; 2010. p. 38-69.

5. Chang JS, Chey MH, Huh MS. The cultural sustainability of squat outhouse toilets in rural and urban arean: a case study of the Yanbian region in China. Int. J. Green Eng. Manag. 2012;1:84-94.

6. Bath area, Mohenjo-daro in Sindh, Pakistan [Internet]. San Francisco: harappa.com; c2008 [cited 2014 Apr 15]. Available from: http://www.harappa.com/indus/12.html.

7. Cho UH, Hyun YJ. Ubiquitous toilet. Seoul: Yocheolyo Publishing; 2006.

8. US Environemntal Protection Agency. Wastewater technology fact sheet: high-efficiency toilets (EPA 832-F-00-047). Washington: Environemntal Protection Agency; 2000.

9. US Environmental Protection Agency. Water efficiency technology fact sheet: incinerating toilets (EPA 832-F-99-072). Washington: Environemntal Protection Agency; 1999.

10. Langergraber G, Muellegger E. Ecological sanitation: a way to solve global sanitaion problems? Environ. Int. 2005;31:433444.

11. Zhang ZN, Su G, Ge GL, Zhao GY, Wu ZY. Rural sanitary domestic flushing toilet system. Water Res. 1996;30:2826-2829.

12. Quitzau MB. Water-flushing toilets: systemic development and path-dependent characteristics and their bearing on technological alternatives. Technol. Soc. 2007;29:351-360.

13. Zavala MA, Funamizu N, Takakuwa T. Biological activity in the composting reactor of the bio-toilet system. Bioresour. Technol. 2005;96:805-812.

14. Hotta S, Funamizu N. Simulation of accumulated matter from human feces in the sawdust matrix of the composting toilet. Bioresour. Technol. 2009;100:1310-1314.

15. Lindholm O, Greatorex JM, Paruch AM. Comparison of methods for calculation of sustainability indices for alternative sewerage systems: theoretical and practical considerations. Ecol. Indic. 2007;7:71-78.

16. Redlinger T, Graham J, Corella-Barud V, Avitia R. Survival of fecal coliforms in dry-composting toilets. Appl. Environ. Microbiol. 2001;67:4036-4040.

17. Tonner-Klank L, Moller J, Forslund A, Dalsgaard A. Microbiological assessments of compost toilets: in situ measurements and laboratory studies on the survival of fecal microbial indicators using sentinel chambers. Waste Manag. 2007;27:11441154.

18. Borsuk ME, Maurer M, Lienert J, Larsen TA. Charting a path for innovative toilet technology using multicriteria decision analysis. Environ. Sci. Technol. 2008;42:1855-1862.
19. Lienert J, Larsen TA. High acceptance of urine source separation in seven European countries: a review. Environ. Sci. Technol. 2010;44:556-566.

20. Cai D, You M. An ergonomic approach to public squattingtype toilet design. Appl. Ergon. 1998;29:147-153.

21. Mamee W, Sahachaisaeree N. Public toilet design criteria for users with walking disability in conjunction of universal design paradigm. Procedia Soc. Behav. Sci. 2010;5:1246-1250.

22. Blum NJ, Taubman B, Nemeth N. Why is toilet training occurrig at older? A study of factors associated with alter training. J. Pediatr. 2004;145:107-111.

23. Lienert J, Larsen TA. Considering user attitude in early development of environmentally friendly technology: a case study of NoMix toilets. Environ. Sci. Technol. 2006;40:4838-4844.

24. You M, Cai D, Chen W. A case study of the design and evaluation of squatting-type toilet for public lavatories. Proceedings of the 7th TVE Conference of ROC; 1992 Mar 20-21; Pingtung, Taiwan

25. Hephaestus Books. Toilet types, including: flush toilet, squat toilet, composting toilet, chemical toilet, blair toilet, clivus multrum, board toilet, accessible toilet, arborloo, dual flush toilet, pail closet. [place unknown]: Hephaestus Books; 2011.

26. Anand C, Apul DS. Economic and environmental analysis of standard, high efficiency, rainwater flushed, and composting toilets. J. Environ. Manag. 2011;92:419-428.

27. Nasir A, Korejo R, Noorani KJ. Child birth in squatting position. J. Pak. Med. Assoc. 2007;57:19-22.

28. Tung YC, Hu SC, Tsai TY. Influence of bathroom ventilation rates and toilet location on odor removal. Build. Environ. 2009;44:1810-1817.

29. Howard G, Bogh C. Healthy villages: a guide for communities and community health workers. Geneva: World Health Organization; 2002.

30. Batterman S, Eisenberg J, Hardin R, et al. Sustainable control of water-related infectious diseases: a review and proposal for interdisciplinary health-based systems research. Environ. Health Perspect. 2009;117:1023-1032.

31. Bridle KL, Kirkpatrick JB. An analysis of the breakdown of paper products (toilet paper, tissues and tampons) in natural environments, Tasmania, Australia. J. Environ. Manag. 2005;74:21-30.

32. Del Porto D, Steinfeld C. The composting toilet system book. Concord: The Center for Ecological Pollution; 2000. p.125166.

33. March JG, Gual M, Orozco F. Experiences on greywater re-use for toilet flushing in a hotel (Mallorca Island, Spain). Desalination 2004;164:241-247. 